How to cite: Rîndaşu-Beuran, S.I., Adam, B.O., Nacu, S., Obreja, R., Săliştean, I.E., Safta, C.A. (2020) Effects Produced by the Flash-Flood from June 1-2, 2019 in the Drainage Basin of the Pian, Rachita and Cioara Rivers (Mureș Drainage Basin). 2020 "'Air and Water-Components of the Environment" Conference Proceedings, ClujNapoca, Romania, p. 93-104, DOI: 10.24193/AWC2020_09.

\title{
EFFECTS PRODUCED BY THE FLASH-FLOOD FROM JUNE 1-2, 2019 IN THE DRAINAGE BASIN OF THE PIAN, RACHITA AND CIOARA RIVERS (MUREȘ DRAINAGE BASIN)
}

\author{
Sorin Ionel RÎNDAŞU-BEURAN ${ }^{1}$, Bianca Otilia ADAM ${ }^{1}$, Simion NACU ${ }^{1}$, \\ Răzvan OBREJA', Ioana Elena SALLIŞTEAN ${ }^{3}$, Costel Adrian SAFTA ${ }^{3}$
}

DOI: 10.24193/AWC2020_09

\begin{abstract}
The area affected by the floods that took place during $1^{\text {st }}-2^{\text {nd }}$ of June 2019 is located in the southern part of Alba county, where significant precipitation had fallen in a very short time. The Pianu, Cioara si Rachita catchment areas are not monitored either from a hydrological or from a rainfall point of view. The rapid floods formed on the Pianu, Cioara and Răchita rivers with their cadastred and non-cadastred tributaries caused great damage in 4 municipalities (Pianu, Săsciori, Săliştea and Şibot): there were flows and extraordinary levels on Răchita and Cioara rivers. The largest damages were recorded in Pianu and Săsciori municipalities, whereas the lowest ones were enlisted at Şibot. The greatest destruction was made by Răchita river, that is $5 \mathrm{~km}$ long, followed by Pianu River. The flash floods affected households, institutions, county roads, street roads, forest roads, water and sewage networks, sewage plants, electricity and gas networks, telephony networks, cultural centres, shops, bridges, footbridges, pedestrian bridges, and agricultural crops. The total amount of the damages caused by flash floods on June $1^{\text {st }}$, 2019 was estimated at around 44.674,864 thousand lei, almost half of which were recorded in the radius of Pianu municipality. There were no human casualties, instead the flash-flood on Cioara river caught in and drowned 213 small animals. On Răchita river there was recorded a historical flash-flood, with a probability of occurrence of once every 200 years, whereas the historical flash-flood recorded on Cioara river (upstream the confluence with Freman river) had a probability of occurrence of once every 130 years; on Pianu river (at Pianu de Sus), the probability of occurrence was once every 35 years.
\end{abstract}

Keywords: torrential rain, flash-flood, dwelling, effects of the flash-flood

\section{INTRODUCTION}

Alba County is located in the mid-western part of the country [1], occupying an area of $6241.57 \mathrm{~km}^{2}$ that represents $2.6 \%$ of the country's surface area, being the $16^{\text {th }}$ county in Romania.

\footnotetext{
1 "Romanian Waters" National Administration, 010018, Bucharest, Romania, e-mail: sorin.randasu@ rowater.ro, bianca.adam@ rowater.ro, simion.nacu@ rowater.ro

2 Water Basin Administration Mureş, 400001, Târgu-Mureş, Romania, e-mail: razvan.obreja@sgams.dam.rowater.ro

3 Water Basin Administration Mureş-SGA Alba, Alba Iulia, Romania, e-mail: ioana.salistean@sgaab.dam.rowater.ro,costel.safta@sgaab.dam.rowater.ro
} 
The area affected by the floods of June 1-2 2019 is located in the south of Alba County and includes the municipalities of Pianu, Săliștea, Săciori and Șibot (Fig. 1).

The slopes of the valleys are partly covered with broadleaf forests of various ages, logging being encountered on some areas.

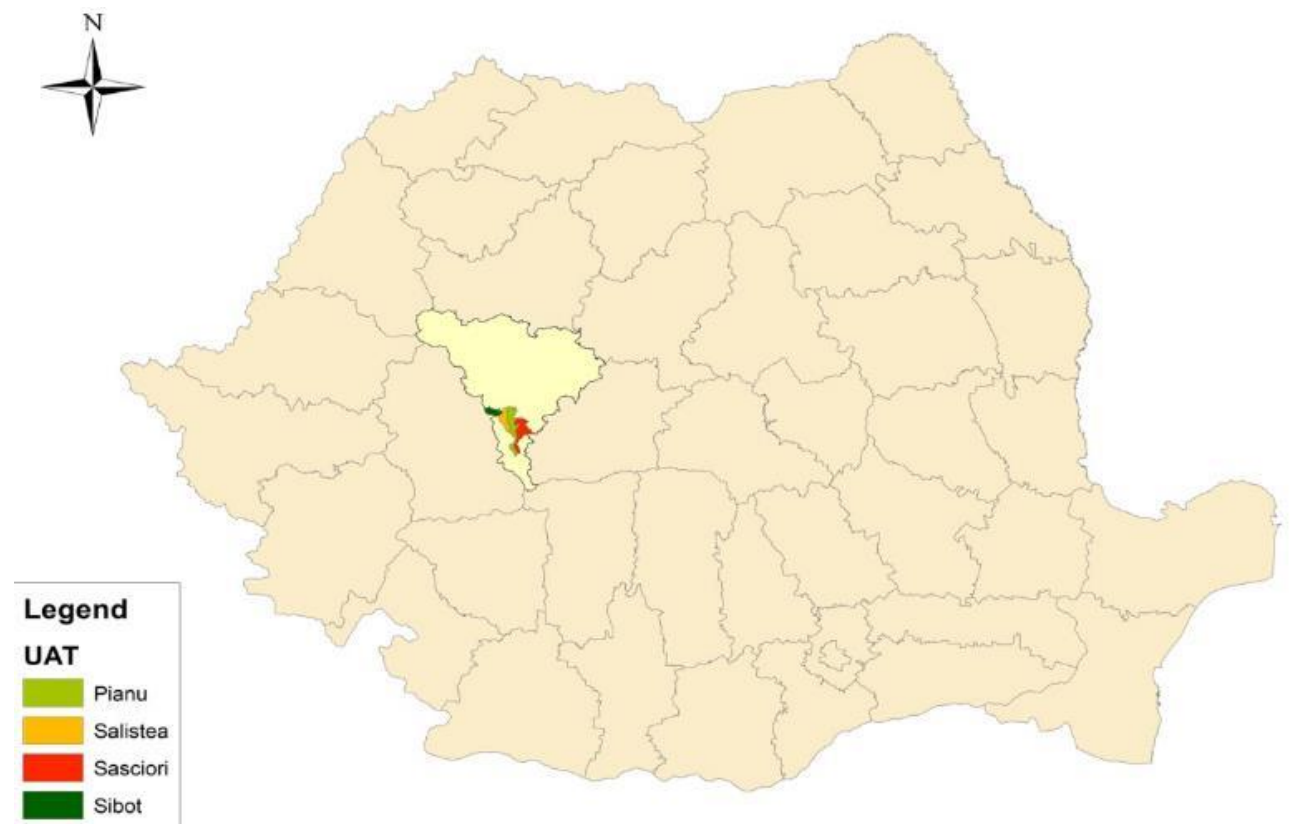

Fig. 1. Geographical position of Alba County

Because of its geographical location, Alba county falls under the preponderant influence of the western movement of air masses [1], to which are added the influences of the polar or tropical air movement, depending upon the position and intensity of the main baric systems (cyclones and anticyclones - that generate and permanently influence these forms of air circulation in the lower layers atmosphere (cyclones and anticyclones - that generate and permanently influence these forms of air circulation in the lower layers atmosphere). Apuseni and Șureanu mountains in the west and south respectively constitute a climate barrier in the horizontal movement of air masses [7].

Pianu River (Mardile) -cadastral code IV-1.104, is tributary to the left of the Mureș River [2,3]. It springs from the Lung Hill (1 $239.5 \mathrm{~m})$ at an altitude of $1225 \mathrm{~m}$ and flows into the Mureș river in the near of Vințu de Jos, at an altitude of $211 \mathrm{~m}$. Pianu

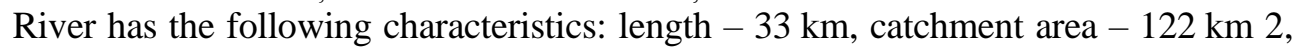
average elevation $-607 \mathrm{~m}$, forest area -5205 ha [3]. Up, until upstream of the confluence with the Valea Tonii river, it has an average slope of $57 \%$; upstream of the confluence with the Ghenea it has an average slope of $56 \%$, the average slope throughout the entire river being $52 \%$ and the sinuosity coefficient $-1,09$. As tributary streams, there are Valea Tonii river - right tributary, and Ghenea river - left tributary. The Valea Tonii river - cadastral code IV-1.104.1 [3], springs from Dealu Stroe (1 $106.5 \mathrm{~m})$ at an altitude of $1000 \mathrm{~m}$ and flows into the Pianu river at an altitude 
of $423 \mathrm{~m}$ in the near of Strungari village, is $8 \mathrm{~km}$ long, with $20 \mathrm{~km}^{2}$ catchment area, the average elevation $-803 \mathrm{~m}$, the forest area $-710 \mathrm{ha}$, the average slope throughout the entire river $-72 \%$ and the the sinuosity coefficient -1.24 [3]. The Ghenea creek - cadastral code IV-1.104.2 - is $9 \mathrm{~km}$ long, with $13 \mathrm{~km}^{2}$ catchment area, an average elevation of $716 \mathrm{~m}$ ( $980 \mathrm{~m}$ on the spring and $382 \mathrm{~m}$ on the confluence), 852 ha forest area, an average slope of $66 \%$ and the sinuosity coefficient $-1,18$.

The Pianu catchment area is adjacent to the east with the Sebeș river basin, with its tributary Răchita, and to the west with the Cioara (Valea lui Stan) river. (fig 2).

Cioara (Valea lui Stan) river, cadastral code IV-1.106, is a left-tributary of Mureș River, is $17 \mathrm{~km}$ long, with $48 \mathrm{~km}^{2}$ catchment area, an average elevation of $434 \mathrm{~m}$ (700 $\mathrm{m}$ on the spring and $208 \mathrm{~m}$ on the confluence), 2190 ha forest area, an average slope of $38 \%$ to the confluence with the Freman river and of $29 \%$, throughout the whole river, and with sinuosity coefficient of 1,14 . It has a single cadastral tributary, Valea lui Freman, cadastral code IV-1.106.1, which has the following characteristics: length $-7 \mathrm{~km}$, catchment area $-13 \mathrm{~km}^{2}$, average elevation $-432 \mathrm{~m}$ (630 $\mathrm{m}$ on springs and $244 \mathrm{~m}$ on the confluence), forest area -1339 ha, average slope $-55 \%$, and the sinuosity coefficient $-1,16$ [3].

Răchita river, cadastral code IV-1.102.14, is a left-tributary of Sebeș river and has the following characteristics: length $-5 \mathrm{~km}$, catchment area $-10 \mathrm{~km}^{2}$, average elevation ${ }^{-} 452 \mathrm{~m}$ (550 $\mathrm{m}$ on springs and $290 \mathrm{~m}$ on the confluence), forest area $-464 \mathrm{ha}$, average slope $-52 \%$, sinuosity coefficient $-1,14$. It flows into the Petrești lake, laying on Sebeș River [3].

\section{METHODOLOGY}

Topographic maps of 1: 25000 scale and licensed Arc GIS 10.6 of the two institutions (National Administration "Romanian Waters", Bucharest and Mureș Water Basin Administration) were used to achieve the cartographic material.

The study of the out breaking conditions and of the characteristic elements of the flash flood were achieved on the basis of data and conclusions developed by the Mureș Water Basin Administration.

The analysis of the flash floods territorial impact was achieved on the basis of the data provided by the central and territorial specialised services of the Mureș Water Basin Administration, of those provided by the local officials, as well as on the basis of authors' own findings during the field visits.

\section{FLASH FLOODS}

On 1.06.2019 the weather was unstable in the afternoon. CMR 'Transilvania Sud' Sibiu issued the yellow code weather warning no. 37 for the southern area of the Alba county, valid for the 1 June (h. 10.00) - 2 June (h. 06.00) interval. As a result of the evolution of atmospheric instability, CMR 'Transilvania Sud' Sibiu issued the orange 
code alert of dangerous weather conditions No 217 - valid between H. 18.40 and H. 19.30 for the following municipalities: Cugir, Blandiana, Ceru Băcăinţi, Pianu, Săliștea, Săsciori and Șibot. It appears that the cloudy system was stationary in the area and there were recorded heavy rains accompanied by electrical discharges.

CMR 'Transilvania Sud' Sibiu issued the yellow code warning of dangerous weather conditions No 218 - valid between H. 19.45 and H. 21.00 for the municipalities of Sebeș, Câlnic, Cut, Doșat, Săsciori and Șpiring.

The highest rainfalls measured between 1 June (h. 6.00) and 2 June (h. 6.00) were recorded to the Petrești storage on the Sebeș River $-42.8 \mathrm{l} / \mathrm{m}^{2}$. At Cugir hydrological observing station on river Cugir, there were recorded $23,71 / \mathrm{m}^{2}$. The following quantities of precipitation were also recorded on the Sebeș river: $31.6 \mathrm{l} / \mathrm{m}^{2}$ at Nedeiu storage, $20.0 \mathrm{l} / \mathrm{m}^{2}$ at Sebeș hydrological observing station and $17.81 / \mathrm{m}^{2}$ at Tău Bistra storage [4]. It is noted that the largest amounts of precipitation fell in the south area of the county, in the area of the municipalities of Săliștea, Pianu and Săciori (Răchita and Sebeșel villages), where the nucleus of the rain was concentrated, but which is not monitored from a rainfall point of view.

The particularly significant amounts of rain that have fallen, as well as the entrainment of the run-offs from the slopes and the reactivation of some torrents, have led to an increase of the flow rates of small cadastral water streams: Răchita, Pianu (with its tributaries Valea Tonii and Ghenea) and Cioara, with its tributary Freman.

Apparently, the flash flood on Pianu river did not overlap with the flash floods on Valea Tonii and Ghenea rivers and thus the warning level was not exceeded at Vințu de Jos. On the contrary, it appears that the flash flood on Cioara River overlapped with that on the Freman river.

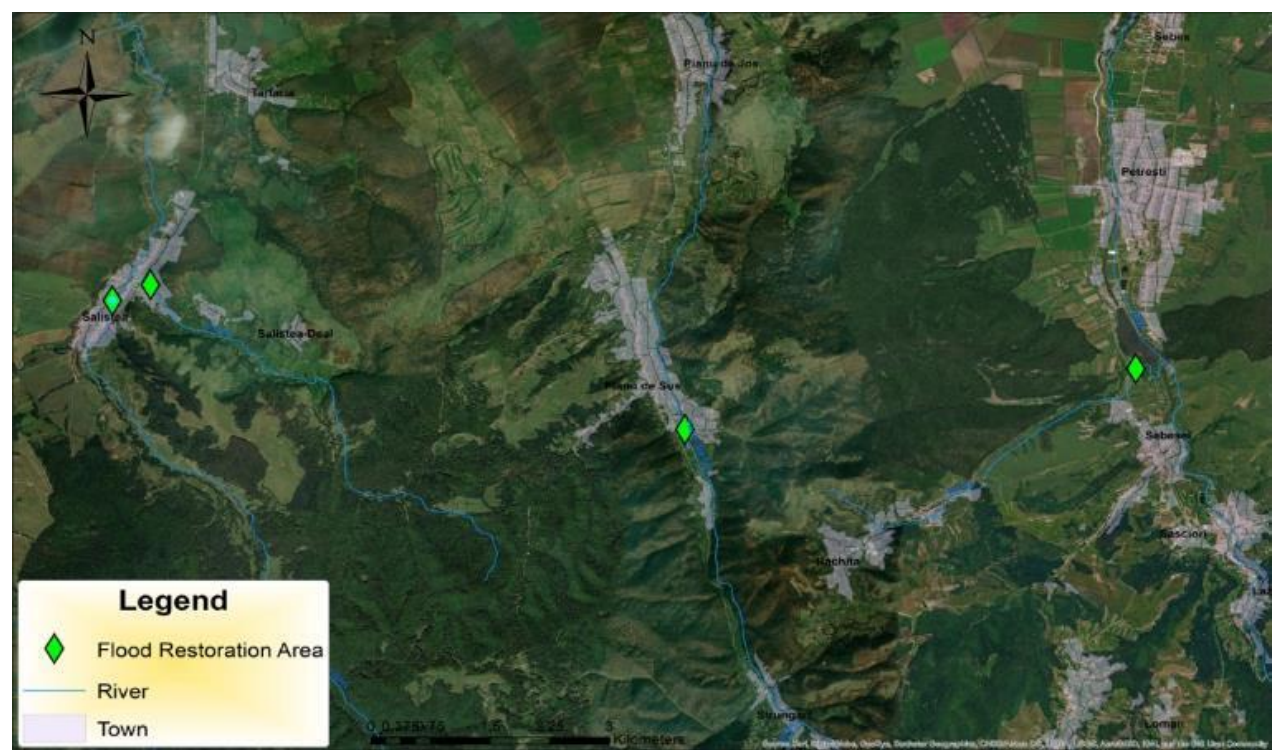

Fig. 2. Flood Restoration Area

Following the reconstitution in the field of the flowing through recorded on Pianu, Cioara and Freeman rivers at June 1 2019, the following values were obtained: 
Răchita river $106 \mathrm{~m}^{3} / \mathrm{s}$, Pianu river (at Pianu de Sus) $114 \mathrm{~m}^{3} / \mathrm{s}$, Pianu river (at Vințu de Jos) $73.5 \mathrm{~m}^{3} / \mathrm{s}$, Freman river (upstream the confluence with Cioara river) $85 \mathrm{~m}^{3} / \mathrm{s}$, Cioara river (upstream the confluence with Freman river) $73 \mathrm{~m}^{3} / \mathrm{s}$, Cioara river (downstream the confluence with Freman river) $158 \mathrm{~m}^{3} / \mathrm{s}$ [4].

Table 1 covers the measurement sections, the maximum flowing through resulting from the reconstitution in the field, and the probability of occurrence for the respective flow rates by comparison with the flow rate of $1 \%$.

Table 1. Hydrological data at gauging stations

\begin{tabular}{|c|l|l|c|c|c|}
\hline $\begin{array}{c}\text { Ref. } \\
\text { no }\end{array}$ & River & \multicolumn{1}{|c|}{ Measurement section } & $\begin{array}{c}\text { Maximum } \\
\text { flowing through }\end{array}$ & $\begin{array}{c}\mathbf{Q}_{\mathbf{1}} \text { \% } \\
\mathbf{m}^{3} / \mathbf{s}\end{array}$ & $\begin{array}{c}\text { Probability of } \\
\text { occurrence }\end{array}$ \\
\hline 1 & Freman & $\begin{array}{l}\text { Upstream the confluence with } \\
\text { Cioara river }\end{array}$ & $85 \mathrm{mc} / \mathrm{s}$ & 57,7 & $\begin{array}{c}\text { Every } 140 \\
\text { years }\end{array}$ \\
\hline 2 & Cioara & $\begin{array}{l}\text { Upstream the confluence with } \\
\text { Freman river }\end{array}$ & $73 \mathrm{mc} / \mathrm{s}$ & 86 & Every 80 years \\
\hline 3 & Cioara & $\begin{array}{l}\text { Downstream the confluence with } \\
\text { Freman river }\end{array}$ & $158 \mathrm{mc} / \mathrm{s}$ & 126 & $\begin{array}{c}\text { Every } 130 \\
\text { years }\end{array}$ \\
\hline 4 & Răchita & $\begin{array}{l}1 \mathrm{~km} \text { upstream upstream of the } \\
\text { confluence }\end{array}$ & $106 \mathrm{mc} / \mathrm{s}$ & 51,5 & $\begin{array}{c}\text { Every } 200 \\
\text { years }\end{array}$ \\
\hline 5 & Pianu & Vințu de Jos hydrological station & $73,5 \mathrm{mc} / \mathrm{s}$ & 230 & Every 30 years \\
\hline 6 & Pianu & Pianu de Sus & $114 \mathrm{mc} / \mathrm{s}$ & 170 & Every 35 years \\
\hline
\end{tabular}

The peak discharge of flash flow at the Vințu de Jos hydrological observing station was $73.5 \mathrm{~m}^{3} / \mathrm{s}$, about 97 times higher than the multiannual average flow rate during the month of June (i.e. $0.758 \mathrm{~m}^{3} / \mathrm{s}$ ). The monthly average flow rate for June 2019 was $1,88 \mathrm{~m}^{3} / \mathrm{s}$, influenced by the values of the flash flood of June 1-2, 2019 .

\section{EFFECTS OF FLASH FLOODS ON THE NATURAL AND AN-MADE ENVIRONMENT}

There were no human casualties, but the flash flood on the Cioara river caught in 213 animals (140 goats, 25 piglets and 50 hens) which drowned, in the village of Balomiru de Câmp (municipality of Șibot) [4]. Table no 2 lists the damages recorded during the flash floods of June 1, $2019[4,5]$.

Table 2. Damages recorded during the flash floods of June 1, 2019

\begin{tabular}{|c|c|c|c|c|}
\hline \multirow{2}{*}{$\begin{array}{c}\text { Ref. } \\
\text { no }\end{array}$} & \multirow{2}{*}{$\begin{array}{c}\text { Affected } \\
\text { municipality }\end{array}$} & \multicolumn{2}{|c|}{ Objectives affected } & \multirow{2}{*}{$\begin{array}{l}\text { Causes of } \\
\text { damages }\end{array}$} \\
\hline & & Physical & $\begin{array}{l}\text { Value - in } \\
\text { thousands of lei }\end{array}$ & \\
\hline \multirow[t]{5}{*}{1} & \multirow{5}{*}{$\begin{array}{l}\text { Municipality } \\
\text { of Pianu } \\
\text { Pianu de Jos } \\
\text { village } \\
\begin{array}{l}\text { Pianu de Sus } \\
\text { village }\end{array}\end{array}$} & Households 239 & 644,5 & \multirow{5}{*}{$\begin{array}{l}\text { Heavy rain } \\
\text { Leakages from } \\
\text { the slopes } \\
\text { Flow rates } \\
\text { fluctuations }\end{array}$} \\
\hline & & County road $6,2 \mathrm{~km}$ & 6967,42 & \\
\hline & & Bridges 3 & 6413,76 & \\
\hline & & $\begin{array}{l}\text { Communal road, streets } 4,2 \\
\mathrm{~km}\end{array}$ & 3700 & \\
\hline & & Pedestrian bridges & 200 & \\
\hline
\end{tabular}




\begin{tabular}{|c|c|c|c|c|}
\hline & Strungari & Culverts 7 & 100 & Flash floods on \\
\hline & village & Forest roads $6,5 \mathrm{~km}$ & 2200 & Valea Măcui, \\
\hline & & Telephone network - $1 \mathrm{~km}$ & 18,56 & Valea Cornii and \\
\hline & & Agricultural crops 8,69 ha & 65,732 & Valea Leii \\
\hline & & $\begin{array}{l}\text { Water supply and sewerage } \\
\text { networks } 0,26 \mathrm{~km}\end{array}$ & 94,136 & torrents \\
\hline & & Electric grid $-0.2 \mathrm{~km}$ & 10 & \\
\hline & & Affected hydraulic works & 1762,958 & \\
\hline 2 & Municipality of & $\begin{array}{ll}\text { Households } 147 \\
\end{array}$ & 1372,75 & Heavy rain \\
\hline & Săciori & County road $4 \mathrm{~km}$ & 14398,81 & Leakages from \\
\hline & Răchita village & Bridges 3 & 4085,65 & the slopes \\
\hline & Sebeșel village & Concrete retaining wall $0,03 \mathrm{~km}$ & 22,56 & Flow rates \\
\hline & & Community center 1 & 8,03 & fluctuations \\
\hline & & Wasted water treatment plant 1 & 68,25 & Flash floods on \\
\hline & & Sewerage network $0,6 \mathrm{~km}$ & 6,14 & the Răchita creek \\
\hline & & Streets $\quad 0,945 \mathrm{~km}$ & 54 & $\begin{array}{l}\text { and on the valea } \\
\text { Beiului torrent }\end{array}$ \\
\hline & & $\begin{array}{l}\text { Water course erosion and silting- } \\
\text { up } 3,35 \mathrm{~km}\end{array}$ & 238 & \\
\hline & & Electric grids $-2.5 \mathrm{~km}$ & 262 & \\
\hline & & Telephone network $-2 \mathrm{~km}$ & 47,82 & \\
\hline & & $\begin{array}{l}\text { Water supply and sewerage } \\
\text { networks } 0,17 \mathrm{~km}\end{array}$ & 114 & \\
\hline & & Gas grid $0,015 \mathrm{~km}$ & 58,254 & \\
\hline & & Agricultural crops $6,6 \mathrm{ha}$ & 28,728 & \\
\hline 3 & Municipality of & Households 79 & 543,33 & Heavy rain \\
\hline & $\begin{array}{l}\text { Săliștea } \\
\text { Săliștea village }\end{array}$ & Local administration goods & 22,21 & $\begin{array}{ll}\text { Leakages from } \\
\text { the slopes }\end{array}$ \\
\hline & & Culverts 5 & 7,18 & Flow rates \\
\hline & & Streets $0,95 \mathrm{~km}$ & 572,6 & fluctuations \\
\hline & & Forest road $5,15 \mathrm{~km}$ & 182,5 & Rapid flash \\
\hline & & Farm road $-0,022 \mathrm{~km}$ & 1,1 & floods on Cioara \\
\hline & & Forest bridges 3 & 60 & river, on Freman \\
\hline & & Communal road bridge 1 & 1,92 & river and on \\
\hline & & Football field 1 & 56,22 & (Oarbei \\
\hline & & $\begin{array}{l}\text { Water supply and sewerage } \\
\text { networks } 0,1 \mathrm{~km}\end{array}$ & 30 & $\begin{array}{lr}\text { creek, } & \text { Soculu1 } \\
\text { creek, } & \text { Sentea }\end{array}$ \\
\hline & & Gas grid $0,02 \mathrm{~km}$ & 23,114 & \\
\hline & & Agricultural crops 0,53 ha & 2,432 & \\
\hline 4 & $\begin{array}{l}\text { Municipality } \\
\text { of Șibot } \\
\text { Balomiru de } \\
\text { Câmp village }\end{array}$ & $\begin{array}{l}\text { Dead animals } 213 \\
\text { Of which: goats } 140, \\
\text { piglets } 23 \text {, hens }\end{array}$ & 27 & $\begin{array}{l}\text { Heavy rain } \\
\text { Leakages from } \\
\text { the } \\
\text { torrents }\end{array}$ \\
\hline
\end{tabular}

\section{AFFECTED HYDRAULIC WORKS AND RIVERBEDS}

Pianu River (Mardile), is developed on two sectors: first sector lays in the near of Strungari village, whereas the second sector is located downstream of Strungari village. In the village of Strungari there is a riverbed regularization of 700 metres 
length whereas, downstream, Pianu river is regulated on both sides, with a 17970 meters length of the regularised bed $[7,8]$.

Răchita river is not developed from a hydrotechnical point of view, but there are some sectors with concrete retaining wall that protects the local road or the county road.

Neither Cioara river nor its tributary Freman are hydrotechnical developed.

Răchita river caused erosion and silting of the riverbed over a length of $3.35 \mathrm{~km}$, and a concrete retaining wall in Sebeșel village was affected over a length of $0.03 \mathrm{~km}$, with an estimated value of the damages to the hydrotechnical constructions of 1762.958 thousand lei. In the radius of Săliștea municipality, Cioara and Freman rivers produced important water course erosions and siltings over a length of $3.7 \mathrm{~km}$ [5].

In the radius of Pianu village, the leakages from the slopes, torrents and the important water discharges which flowed in a very short time have silted the riverbed of Pianu river over a $10 \mathrm{~km}$ length. 9 bottom sills were destroyed whereas 5 bottom sill were clogged. There were two sectors on the river Pianu were the riverbed silted - first, between the villages of Strungari and Pianu de Sus (Fig.3), and the second between Pianu de Sus and Pianu village, where a pitch caused a riverbed change, the river forming a new one (PM5).

The riverbed unsilt and recalibrating works developed downstream of Strugari village are shown in Figure 4.

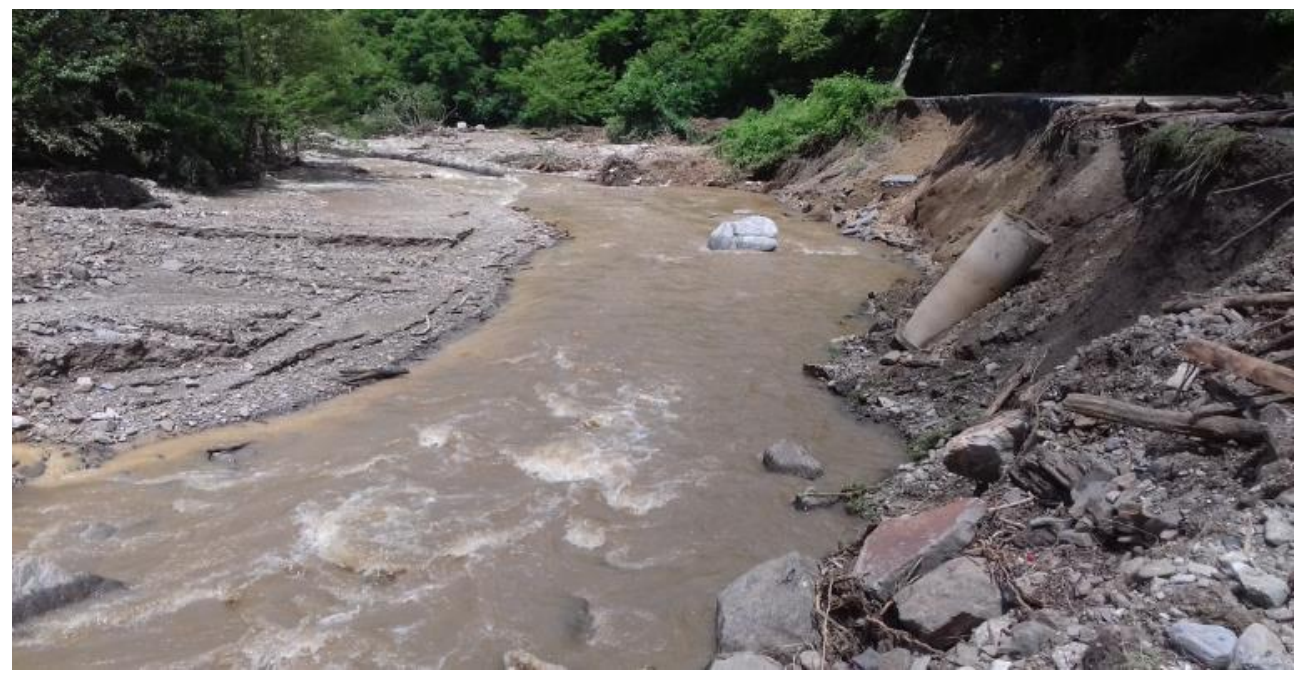

Fig. 3. Riverbed and communal road erosion - downstream of Strungari village - photo C.A. SAFTA

The water-course regulation works were affected as follows: $0.19 \mathrm{~km}$ gabion wall bank protection, $0.018 \mathrm{~km}$ embankment shore protection, $1.3 \mathrm{~km}$ flood defence works. The thalweg of Pianu river riverbed deepened over a length of $1.4 \mathrm{~km}$ and the banks were eroded over a $0.55 \mathrm{~km}$ length $[4,5]$.

Following the events of June 1, 2019, the SGA Alba amended the 2019 Technical Plan and mobilised in disaster areas all the fitted hydro-ameliorative machinery and 
lorries. The works were carry out with 2 backhoe loaders, 3 excavators, 1 bulldozer and 3 lorries.

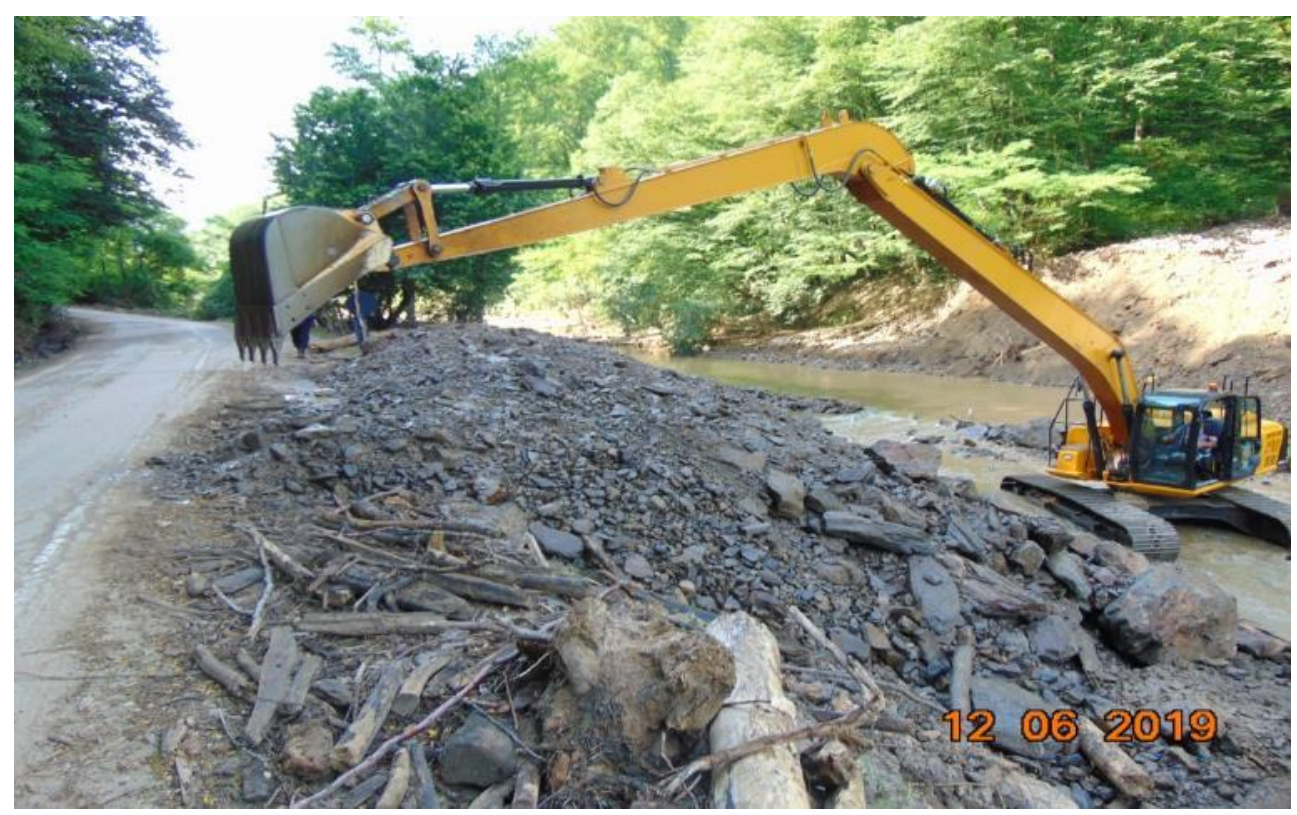

Fig. 4 Pianu riverbed recalibration - downstream of Strungari village - photo C.A. SAFTA

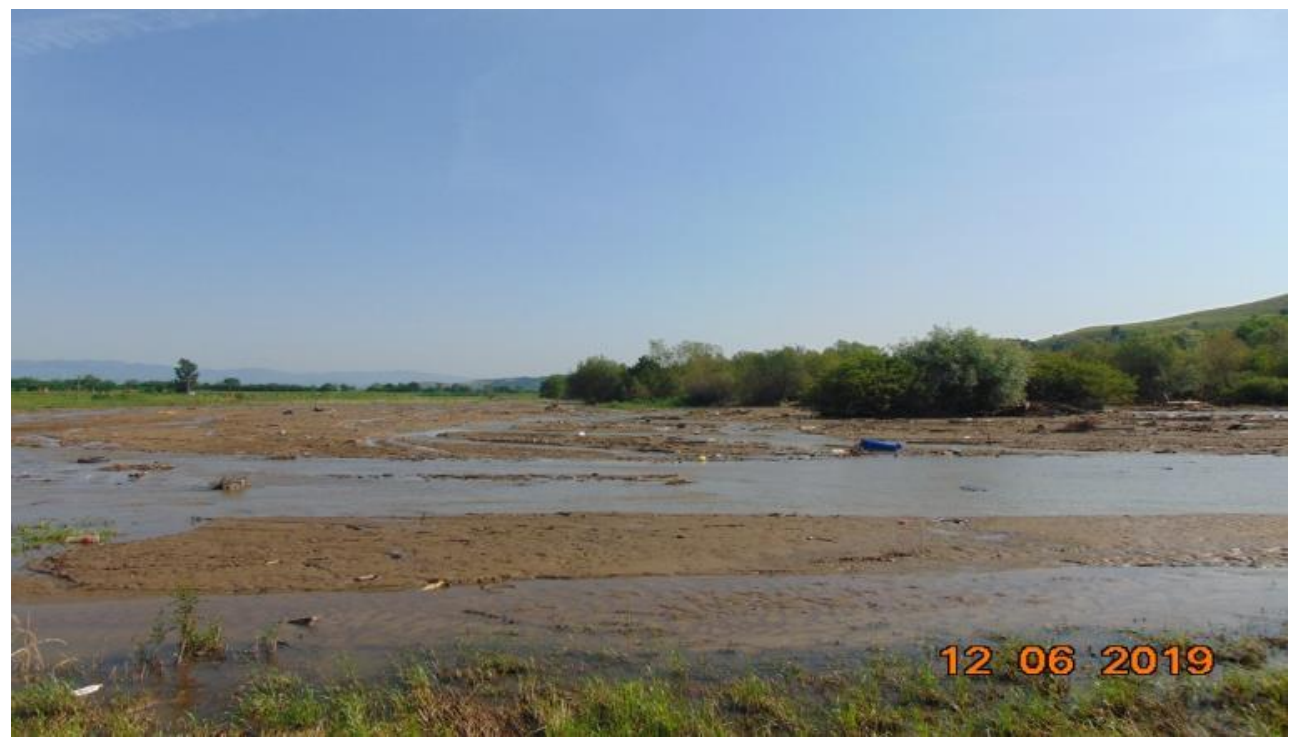

Fig. 5 Silting and riverbed change - downstream of Pianu de Sus - photo C.A. SAFTA 


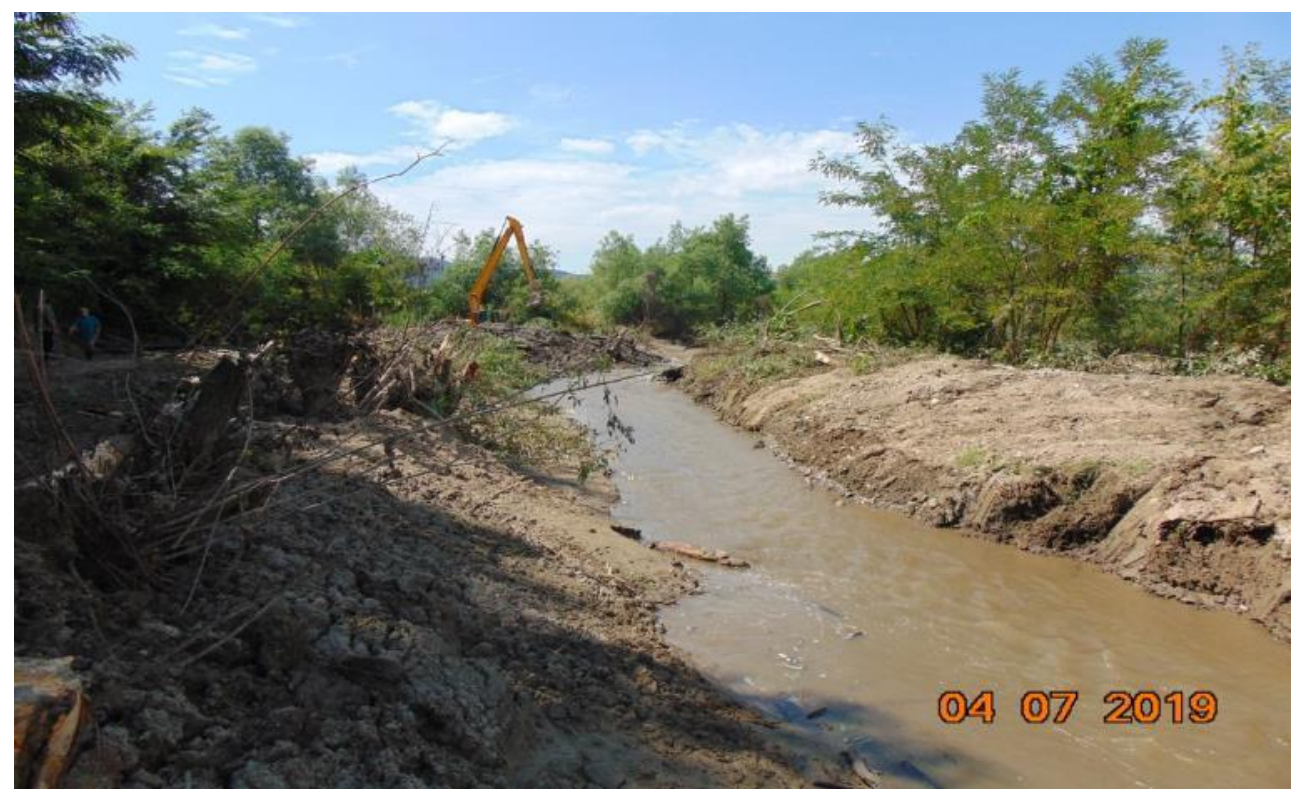

Fig. 6. Riverbed unsilt and restoring the old riverbed of Pianu river - photo C.A. SAFTA

The situation of works carried out under the Technical Plan is shown in Table 3.

Table 3. Status of the works carried out as a matter of urgency by the SGA Alba

\begin{tabular}{|c|l|l|c|}
\hline \multirow{2}{*}{$\begin{array}{c}\text { Num } \\
\text { ber }\end{array}$} & \multicolumn{1}{|c|}{$\begin{array}{c}\text { Works } \\
\text { Denomination }\end{array}$} & Works carried out under Technical Plan 2019 & $\begin{array}{c}\text { Palue (thousands } \\
\text { of lei) }\end{array}$ \\
\cline { 3 - 4 } & $\begin{array}{l}\text { Răchita river } \\
\text { development }\end{array}$ & $\begin{array}{l}\text { Water course sanitation }-5 \mathrm{~km} \\
\text { Re-profiling, riverbed unsilting }-5 \mathrm{~km} / 14600 \mathrm{~m}^{3}\end{array}$ & 70,7 \\
\hline 2 & $\begin{array}{l}\text { Pianu river and } \\
\text { tributaries } \\
\text { development }\end{array}$ & $\begin{array}{l}3 \mathrm{~km} \text { water course } \\
\text { Re-profiling, riverbed unsilting }-3 \mathrm{~km} / 11500 \mathrm{~m}^{3}\end{array}$ & 35,6 \\
\hline 3 & $\begin{array}{l}\text { Cioara and Freman } \\
\text { rivers development }\end{array}$ & $\begin{array}{l}2 \mathrm{~km} \text { water course } \\
\text { Re-profiling, riverbed unsilting }-2 \mathrm{~km} / 3500 \mathrm{~m}^{3}\end{array}$ & 15,8 \\
\hline
\end{tabular}

\section{EVENTS IN THE STUDY AREA}

The south area of Alba County comprises the municipalities of Cugir, Pianu, Săliștea, Săsciori, Șibot and Șugag. There were counted the events occurred during the 2006-2019 period and it results that the most affected area was the Pianu municipality -12 events, followed by the town of Cugir -11 events and the municipality of Șugag - 10 events.(figure 4). The least affected were the municipalities of Săciori - 6 events and Săliștea -5 events [6]. 


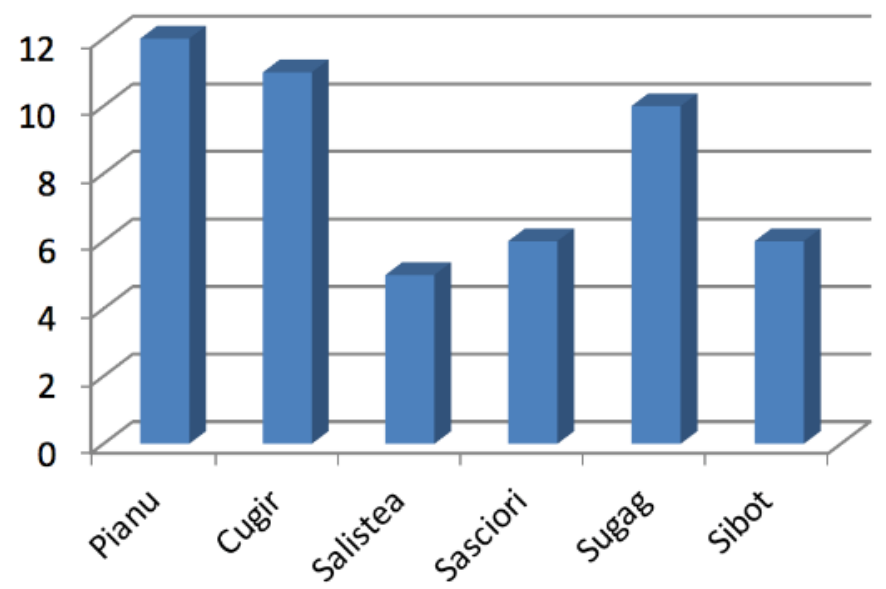

Fig. 8. Number of events for the 2006-2019 period

For the 2014-2019 period, there were 5 events in the radius of the Pianu municipality, of which the June 1, 2019 and June 10, 2018 events produced the greatest damages. In both events, Valea Leii river caused significant damages (figure 5).

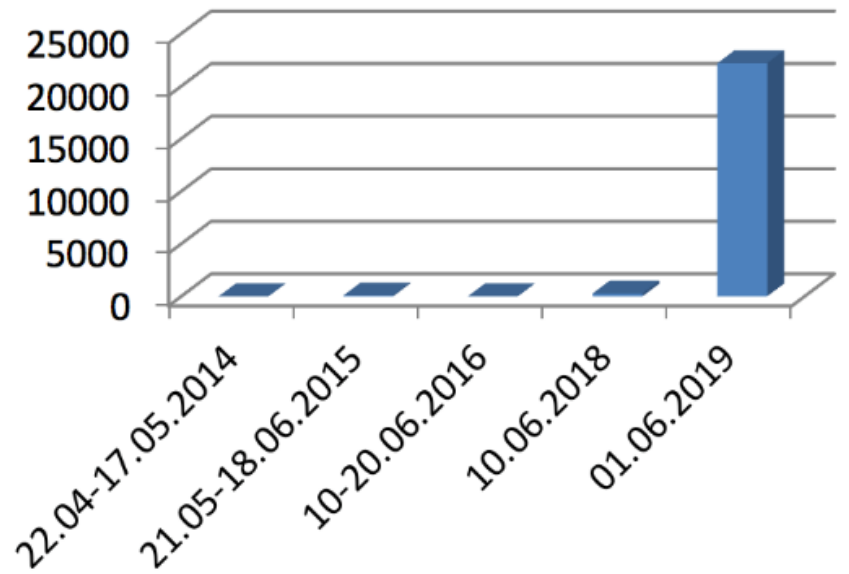

Fig. 9. Pianu events 2014-2019

The events produced in 2014, 2015 and 2016 did not record large damages. The June 1, 2019 event was the greatest, both in terms of flash floods and resulting damages.

Pianu, Săliștea, Săciori and Șibot municipalities have been affected, the total value of the damages being RON 44674.864 thousand lei, with Pianu and Săsciori municipalities being the most affected (Figure 6).The municipality of Șugag was not affected by the event [6]. 


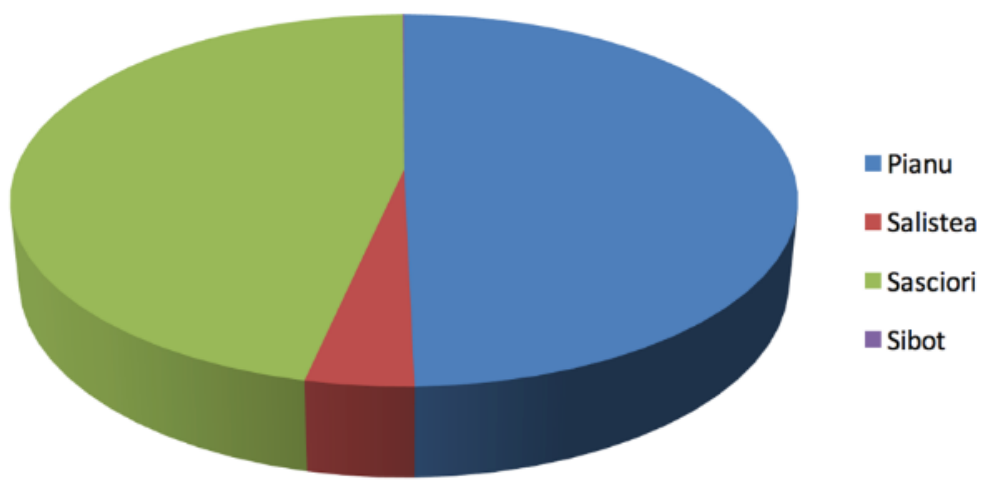

Fig. 10. Damages caused to municipalities 1.06.2019

\section{CONCLUSIONS}

Municipalities of Pianu (with Pianu de Sus, Pianu de Jos, Strugari villages) and Săciori (with Răchita and Sebeșel villages) were the most affected by the June 1, 2019 event, with a total damages of RON 44674.864 thousand lei.

Flash floods on Pianu, Răchita, Cioara, Freman and Valea Leii rivers are frequent frequent phenomena, being produced by heavy rainfall, often torrential. Undeveloped rivers, the unsanitized torrents' streambeds and valleys, plant debris withdrawn after logging - all these lead to widespread flash floods and riverbed pitches, to the first obstacles bridge-type or narrowings.

Flash floods of June 1, 2019 were exceptional events for Răchita, Freman, Cioara and Valea Leii rivers.

The municipalities of Pianu, Cugir and Șugag were the most affected by the floods in the 2006-2019 period. The Șugag municipality was not affected by the June 1, 2019 event.

The municipalities of Săliștea, Pianu (with Pianu de Sus, Pianu de Jos, Strugari villages) and Săsciori (with Răchita and Sebeșel villages) are located along Cioara, Pianu and Răchita rivers, and there is permanent risk of flooding in case of a heavy rain event.

Since many of the damages produced in the radius of Strungari village were produced by Valea Leii river (unregistered from a cadastral point of view), the municipality of Pianu needs to take steps to obtain funds to regularise this water course.

Forest District of Pianu will have to manage the torrents in its area of activity.

There were no human casualties, but the flood on Cioara river caught in and drowned 213 animals (140 goats, 23 piglets and 50 hens). 


\section{REFERENCES}

1. Morariu, T., Bogdan Octavia, Maier, A. (1980), Judeţul Alba, Editura Academiei RSR, Bucureşti

2. Diaconu, C., (1971) Rîurile României-monografie hidrologicăa, Institutul de Meteorologie şi Hidrologie, Bucureşti;

3. ***, (1992), Atlasul cadastrului apelor din România, Ministerul Mediului,, Bucureşti.

4. ***., (2019), Rapoarte de sinteză ale Administraţiei Bazinale de Apă Mureş

5. ***, (2019) Rapoarte operative ale primăriilor Sălişte, Pianu şi Săsciori.

6. *** Arhiva Administraţiei Naţionale "Apele Române "Bucureşti..

7. ***, (2018), Plan județean de apărare împotriva inundaţiilor pentru perioada 20182021, judeţ Alba

8. *** (2016), Planul de analiză şi acoperire a riscurilor -judeţul Alba; Consiliul Judeţean Alba, Alba-Iulia; https://www.cjalba.ro/wpcontent/uploads/2016/06/PAAR2016AB.pdf 